\title{
Sınıf Öğretmeni Adaylarının Elektrik Kavramına İlişkin Bilişsel Yapıları
}

\author{
Salih UZUN*, Günay PALİÇ ŞADOĞLU** \\ * Uşak Üniversitesi, Uşak, TÜRKIYY; ${ }^{* *}$ Recep Tayyip Erdoğan Üniversitesi, \\ Rize, TÜRKIYYE
}

Makale Gönderme Tarihi : 27.12.2016

Makale Kabul Tarihi: 06.10.2017

Özet - Bireylerin bilgileri nasıl yapılandırdıklarını anlama eğitim araştırmacılarının önemli ilgi alanlarından birisi olmuş ve bu kapsamda öğrenenlerin bilişsel yapılarını ortaya çıkarmaya çalışan birçok araştırma yapılmıştır. Bu çalışmanın amacı, sınıf öğretmeni adaylarının elektrik kavramı ile ilgili bilişsel yapılarını tespit etmektir. Bu kapsamda veri toplama aracı olarak bağımsız kelime ilişkilendirme testi kullanılmış ve veriler içerik analizi yapılarak çözümlenmiştir. Ayrıca katılımcılardan, elektrik uyarıcı kelimesi ile ilişkili cümleler oluşturmaları istenilmiş ve oluşturulan cümleler önceden belirlenen kategoriler dikkate alınarak analiz edilmiştir. Çalışmanın örneklemini, eğitim fakültesi 3. sınıfta öğrenim gören toplam 35 sınıf öğretmeni adayı oluşturmaktadır. Elde edilen bulgular, katılımcıların uyarıcı kelime olarak sunulan elektrik kavramına ilişkin zihinlerinde yer alan kelimelerin 9 kategori altında toplandığını ortaya koymuştur. "Elektrik devre elemanları" olarak belirlenen kategorinin ön plana çıktığı görülmüştür. Öğretmen adaylarının elektrik kavramıyla sıklıkla ilişkilendirdikleri kelimelerin ampul, ışık, akım, direnç, anahtar ve pil olduğu belirlenmiştir. Ayrıca öğretmen adaylarının elektrik kavramını, temel düzeydeki bilgiler çerçevesinde ilişkilendirdikleri ve ileri düzeyde bilgiye dayalı kelimelerle/kavramlarla ilişkilendirmedikleri görülmektedir.

Anahtar kelimeler: bilişsel yapı, kelime ilişkilendirme testi, sınıf öğretmen adayı, elektrik

\section{Genişletilmiş Özet}

\section{Giriş}

Bireylerin bilgiyi nasıl yapılandırdıklarını anlama, eğitim araştırmacılarının önemli ilgi alanlarından birisi olmuş ve bu kapsamda öğrenenlerin bilişsel yapılarını belirlemeye yönelik

\footnotetext{
* Sorumlu Yazar: Yrd. Doç. Dr., Uşak Üniversitesi, Eğitim Fakültesi, Matematik ve Fen Bilimleri Eğitimi Bölümü, Uşak, Türkiye

E-mail: salih.uzun@usak.edu.tr
} 
birçok araştırma yapılmıştır (Tsai \& Huang, 2002). Bir bireyin uzun süreli belleğindeki kavramların ilişkilerini sergileyen bilişsel yapının (Shavelson 1972; Shavelson, 1974; Kurt, 2013), özellikle de geleceğin öğretmenleri olacak öğretmen adaylarının öğretecekleri temel kavramlar çerçevesinde ortaya konulması önemlidir. Bunun yanında, fen bilimleri dersinde yer alan temel kavramlardan biri olan "elektrik" kavramı, fizik alanında anlaşılması ve öğretilmesi güç olan temel konular arasında yer almaktadır (Shipstone, 1988; Shipstone, Von Rhöneck, Jung, Kärrqvist, Dupin, Joshua \& Licht, 1988; Küçüközer, 2004). Özellikle elektrik ve ilişkili kavramların fizikte kullanılan anlamlarından farklı olarak günlük dilde kullanıldığ (Duit \& Rhöneck, 1997) ve bunun da ötesinde fizik ders kitaplarında da elektrik ve ilişkili kavramları açıklarken kafa karıştırıcı bir dilin kullanıldı̆̆ı belirtilmektedir (Mulhall, McKittrick, \& Gunstone, 2001). Bu nedenle, fizik dersinde öğretmenin ve öğrencilerin elektrik kavramına yükledikleri anlam farklılıklarının yanlış anlamalara neden olabileceği söylenebilir (Duit \& Rhöneck, 1997). Bu kapsamda bu çalışmada, sınıf öğretmeni adaylarının fen bilimleri dersinin temel kavramlardan biri olan "elektrik" kavramını zihinlerinde nasıl yapılandırdıklarını belirlemek amaçlanmıştır.

\section{Yöntem}

Nitel araştırma yönteminin benimsendiği bu çalışmaya, Eğitim Fakültesinin sınıf öğretmenliği bölümü 3. sınıfinda öğrenim gören toplam 35 öğretmen adayı katılmıştır. Bu araştırmada veri toplama aracı olarak bağımsız kelime ilişkilendirme testi kullanılmıştır. Kelime ilişkilendirme testinin ilk aşamasında, sınıf öğretmeni adaylarından elektrik kavramına dair zihinlerine ilk gelen on kelimeyi 30 sn içerisinde yazmaları istenmiştir (Gussarsky \& Gorodetsky, 1990). Kelime ilişkilendirme testinin ikinci aşamasında ise, sınıf öğretmeni adaylarından 30 sn'lik sürede anahtar kavramla ilgili üç cümle yazmaları istenmiştir. Veriler içerik analizi yöntemine göre analiz edilmiştir. Sınıf öğretmeni adaylarının anahtar kavrama verdikleri cevaplar ayrıntılı bir şekilde incelenmiş ve anahtar kavram için hangi kelimelerin ya da kavramların kaçar defa tekrarlandığını gösteren bir frekans tablosu oluşturulmuştur. Öğretmen adaylarının elektrik kavramına yönelik kurdukları cümleler ise içerdikleri anlamlara göre, Özata-Yücel ve Özkan (2015) tarafından geliştirilen kategoriler dikkate alınarak kategorize edilmiştir. Ayrıca, bu çalışmada iki araştırmacı tarafından yapılan kodlamalar arasındaki güvenirlik katsayısı \% 83 olarak hesaplanmıştır. 


\section{Bulgular}

Öğretmen adaylarının elektrik kavramını çoğunlukla ampul, ışık, akım, direnç, anahtar, pil, elektrik devresi ve enerji ile ilişkilendirdikleri görülmüştür. Öğretmen adaylarının elektrik kavramını ilişkilendirdikleri kavramların çoğunlukla "elektrik devre elemanları", “elektrik üretimi, dağıtımı ve dönüşümü” ve “günlük yaşamla ilişki” kategorilerine yönelik kavramlar olduğu, bunun yanı sıra elektrik kavramının "elektrik akımı”, "iletkenlik”, “devre türü”, “birim”, "bilim insanı” ve "doğal olaylar” ile ilişkili kavramlarla ilişkilendirildiği de belirlenmiştir. Öğretmen adayları tarafından oluşturulan cümleler incelendiğinde, elektrik kavramının genellikle basit elektrik devre elemanları ile ilişkilendirildiği görülmüştür. Öğretmen adaylarının doğru bilimsel bilgi kategorisinde yer alan cümlelerinde, genel olarak elektrik devresi elemanlarının pil, ampul, duy, iletken teller ve anahtardan oluştuğu, elektriğin bir enerji türü olduğu, teknoloji için temel ihtiyaç olduğu ile ilgili ifadelerin yer aldığı görülmüştür. Adayların duyuşsal bilgi kategorisinde yer alan cümlelerinin, elektriğin insanlık için en büyük icat olduğu, hayatı kolaylaştırdığı, elektriğin olumlu etkileri gibi olumsuz etkilerinin de olduğu şeklinde ifadeler içerdiği görülmüştür. Adayların yüzeysel ve günlük hayattan örnekler içeren bilgi kategorisinde yer alan cümlelerinde, elektrikten ssınma ve aydınlanma gibi birçok alanda yararlanıldığg, elektriğin elektrik kablolarıyla iletildiği gibi ifadelerin olduğu görülmüştür. Adayların bilimsel olmayan ve yanılg1 içeren bilgi kategorisinde yer alan cümlelerinde ise, elektriğin artı ve eksi kutuplara sahip bir enerji türü olduğu, elektrik enerjisinin pilden çıkıp kablo aracılığıyla ampulü yaktığı, elektriğin bir güç kaynağ1 olduğu ve elektriğin devre elemanlarıyla eşdeğer olduğu şeklinde ifadeler yer aldığ1 görülmüştür.

\section{Tartışma, Sonuç ve Öneriler}

Çalışmada öğretmen adaylarının elektrik kavramına yönelik zihinlerinde sınırlı sayıda kavramların belirdiği, elektrik kavramıyla sıklıkla ilişkilendirdikleri kelimelerin ampul, 1ş1k, direnç, anahtar ve pil olduğu ve bu kavramların "elektrik devre elemanları" ile ilişkili kavramlar olduğu tespit edilmiştir. Birçok eğitim kademesinde genelde elektrikle ilgili temel kavramların elektrik devresi ile ilişkili verilmesi bu durumun temel gerekçesi olabilir. Bu kapsamda öğretmen adaylarının cümlelerinde bilimsel olmayan kategorisinde yer alan "Elektrik pil, duy, pil yatağı, iletken kablo, direnç, ampul gibi kısımlardan oluşur.” şeklindeki düşüncelerin temelinde elektriği, sıklıkla elektrik devresi üzerinden ilişkilendirmelerinin bir sonucu olabilir. Bunun da ötesinde öğretmen adaylarının elektrikle ilgili daha ileri düzeyde 
bilgi gerektiren kavramlarla ilişkilendirmedikleri ve sınırlı bilgiye dayanan kavramlar düzeyinde ilişkiler kurdukları görülmüştür. Öğretmen adaylarının ilkokul ve ortaokul düzeyinde bilgilere dayalı yapılan bu ilişkilendirmelerinin, lise ve üniversite seviyesinde yeterli fizik dersi almamalarının ve elektrik kavramı ile ilişkili ileri düzeyde konuların öğretilmemesinin bir neticesi olarak düşünülebilir.

Öğretmen adaylarının kurduğu cümlelerde, elektriğe yüklenen anlam insanlık için en büyük icat olduğu, en önemli teknolojik ihtiyaçlardan biri olduğu, hayatı kolaylaştırdığı, elektriğin olumlu etkileri gibi duyuşsal bilgiler yer almıştır. Öğretmen adaylarının kurduğu cümlelerin aynı zamanda elektriğin, ısınma ve aydınlanma gibi birçok alanda yararlanılan bir enerji çeşidi olduğu ve elektrikli araçların iletken kablolar sayesinde çalıştığı şeklinde yüzeysel bilgiler içerdiği de görülmüştür.

Öğretmen adaylarının bilimsel olmayan cümleleri dikkate alındığında özellikle, “Elektrik bir devrede pilden çıkıp kablo aracılı̆̆ıyla ampulü yakan...” vb. ifadelerle elektrik enerjisinin pilde depolandığı ve kablolar aracılığıyla aktarıldığg fikrinin ön plana çıktığ görülmüştür. Benzer şekilde Cheng \& Kwen (1998), Duit \& Rhöneck (1997), Lee \& Law (2001) ve Çıldır \& Şen (2006) yaptıkları çalışmalarda, öğrencilerin elektriğin üreteç/pil içinde depo edildiği fikrine sahip olduklarını ifade etmektedirler. Bazı öğretmen adaylarının ise “Anahtarı açınca lamba ve ampul yardımıyla etrafa ışık enerjisi vermeyi sağlar." gibi ifadeler kullandıkları görülmüştür. Bilindiği üzere bir elektrik devresinde bulunan anahtarın açık olma durumu ampulün yanmamasına neden olacaktır. Öğretmen adayları, elektrik devresindeki anahtarın açık-kapalı olması ile günlük yaşamda lambanın açılması-kapatılması durumlarını, bilimsel açıklama ile uyuşmayacak bir biçimde, eş tutarak ifade etmiştir. $\mathrm{Bu}$ çalışmanın katılımcılarının öğretmen adayları olduğu düşünüldüğünde, öğretmen eğitimi kapsamında özellikle alan derslerinin öğretimi sırasında bu şekilde bilimsel bakış açısıyla örtüşmeyen, günlük yaşam tecrübelerini içeren ve yanlış anlama-yanılgıya sebep olabilecek ifadelerin vurgulanması ile bir farkındalık oluşması sağlanabilir. Bu sayede öğretmen adaylarının gelecekte öğretmen olarak bulunacakları öğrenme ortamlarında bu şekilde ifadeleri kullanmalarının önüne geçilebilir. 


\title{
The Cognitive Structures of Turkish Pre-service Primary Teachers Regarding Electricity
}

\author{
Salih UZUN*, Günay PALİÇ ŞADOĞLU** \\ * Uşak University, Uşak, TURKEY; ** Recep Tayyip Erdoğan University, \\ Rize, TURKEY
}

Abstract - Individuals' knowledge construction is one of the most important areas of interest in educational research and many studies have been carried out attempting to reveal the cognitive structure of learners. The aim of this study was to identify the cognitive structures of pre-service primary teachers (PSPTs) regarding the stimulus word "electricity" through the free word association test. The data were analyzed according to the content analysis method. In addition, participants were asked to generate sentences that related the stimulus word and the sentences were analyzed taking into account the predefined categories. The study sample consisted of 35 third-grade PSPTs at a faculty of education in Turkey. The findings revealed that participants' responses to electricity were gathered under 9 categories and the most obvious category was "circuit components". The findings showed also that the most used words related to electricity were bulb, light, current, resistor, switch, and cell battery. It was also seen that the words and concepts used by the PSPTs related to electricity are based on knowledge at the basic level rather than advanced level.

Key words: cognitive structure, word association test, pre-service primary teacher, electricity

\section{Introduction}

Understanding how individuals think and how they organize knowledge has become one of the major areas of interest of educational researchers and therefore they have developed a variety of techniques which enable the demonstration of learners' cognitive structures (Tsai \& Huang, 2002). Cognitive structure is referred to a hypothetical structure exhibiting associations of concepts in an individual's long-term memory (Shavelson 1972; Shavelson, 1974; Kurt, 2013). Besides, these structures help to make connections by establishing a bridge between the known and the unknown (Garner, 2007). Therefore, the realization of learning requires the reorganization of the learner's cognitive structure

\footnotetext{
* Corresponding Author: Asst. Prof. Dr., Department of Mathematics and Science Education, Usak, Turkey

E-mail: salih.uzun@usak.edu.tr
} 
(Ifenthaler, Masduki, \& Seel, 2011). According to Tsai \& Huang (2002) identifying students' cognitive structures could help teachers to choose appropriate instructional strategies that will provide positive contributions to students' learning. Similarly, Jonassen (1987) pointed out that the identification of learners' cognitive structures helps educators to identify students' knowledge gaps and to choose appropriate teaching materials (as cited in Ifenthaler et al., 2011). Thus, determining future teachers' cognitive structure regarding the fundamental concepts they will teach should be seen as a necessity within the scope of teacher education. This would enable educators to identify appropriate instructional strategies in teacher education programs.

In recent years, the word association test is one of the most widely used techniques to determine the cognitive structure. Bahar, Johnstone, \& Sutcliffe (1999) and Hovardas \& Korfiatis (2006) stated that the word association test is an effective tool enable to reveal connections between concepts and to determine cognitive structure. It is assumed that associative responses retrieval from long-term memory to a given stimulus word in the word association test reflects a significant part of the cognitive structure (Shavelson, 1972; Ifenthaler et al., 2011). Moreover, the word association test could be useful to determine whether it is meaningful that organization of concepts relevant to the subject in students' minds (Şaşmaz-Ören, 2014). It is seen that many studies have been employed to reveal cognitive structures through the word association test in various fields (Shavelson, 1972; Bahar et al., 1999; Kostova \& Radoynovska, 2008; Ercan, Taşdere, \& Ercan, 2010; Iş1klı, Taşdere, \& Göz, 2011; Kurt, 2013; Kurt \& Ekici, 2013; Taşdere, Özsevgeç, \& Türkmen, 2014; Öner-Armağan, 2015; Canbazoğlu-Bilici, 2016).

The basics of science concepts are taught in the primary schools by the primary teachers in Turkey. These basics are taught in Life Science courses in the 1st, 2nd and 3rd grades and also the Science course in the 4th grade of primary schools (Gökulu \& Koç, 2016). Knowledge levels of primary school teachers in science are important because of their science teaching will have a significant impact on the students' future learning in this area. Thus, determining the cognitive structure of pre-service primary teachers (PSPTs) regarding the fundamental concepts which are difficult to understand and to be taught in science will shed light on practices carried out pre-service teacher training and in-service training.

Electricity is also one of the fundamental subjects/concepts which are difficult to understand and teach in science education (Shipstone, 1988; Shipstone, Von Rhöneck, Jung, Kärrqvist, Dupin, Joshua \& Licht, 1988; Küçüközer, 2004). In particular the meanings of 
concepts used in physics, such as electricity, current, and resistor, are known to be different than their use in everyday language (Duit \& Rhöneck, 1997). Moreover, Mulhall, McKittrick, \& Gunstone (2001) pointed out that a confusing language is used when explaining electricity and related concepts in physics textbooks. Therefore, differences in meaning given by teachers and students to the concept of electricity in physics lessons can lead to misunderstandings (Duit \& Rhöneck, 1997). In studies, it is also reported that students have scientifically unacceptable ideas about electricity (Akdeniz, Pektaş, \& Yiğit, 2000; Aykutlu \& Şen, 2012; Çıldır, 2005; Çıldır \& Şen, 2006; Demirci \& Çirkinoğlu, 2004; Dilber \& Düzgün, 2008; Duit \& Rhöneck, 1997; Karal, Alev, \& Yiğit, 2009; Küçüközer, 2004; Lee \& Law, 2001; Yıldırım, Yalçın, Şensoy \& Akçay, 2008).

This study was aimed to identify the cognitive structures of the pre-service primary teachers regarding electricity.

\section{Methodology}

A qualitative research process was adopted as a framework for data collection and analysis in this study. This kind of research is an attempt to reveal the perceptions and events which occur within a natural environment in a realistic and holistic manner through data collection techniques, such as observation, interview, and document analysis (Yıldırım \& Şimşek, 2011). The study sample consisted of 35 third-grade PSPTs at a faculty of education in Turkey.

\section{Data Collection}

The free word association test was used as a data collection tool in this research. The word association test consists of two stages. Participants in the first phase, within a certain period of time (generally 30 seconds) were required to write concepts which were brought to their minds by the stimulus word (Gussarsky \& Gorodetsky, 1990). The stimulus word was written under the other one so as to prevent the risk of a chain response by enabling the participants to return to the stimulus word. In this way, taking into account the concepts/words which the participants' associates (the answers) with the stimulus word, it was aimed to prevent them from writing a subsequent word (Bahar \& Özatl1, 2003). In this study, PSPTs were required to write ten words which first came to mind about the stimulus word "electricity" in 30 seconds. In the second stage, by requesting the writing of three sentences using the stimulus word during the 30 seconds given to participants, it was aimed to 
contribute to determining whether the response (word) is related to the stimulus word (Nartgün, 2006). Also, the sentences, as more complex and high-level structures than one word answer will ensure contributions to determine scientific accuracy of connections in cognitive structure (Ercan, Taşdere, \& Ercan, 2010).

In this study, the free word association test which includes the stimulus word "electricity" is presented in the format given in Table 1.

Table 1 Free word association test layout

\begin{tabular}{|c|}
\hline Electricity \\
\hline Electricity :.... \\
\hline Electricity :... \\
\hline Electricity :.... \\
\hline Electricity :.... \\
\hline Electricity :.... \\
\hline Electricity :....... \\
\hline Electricity :..... \\
\hline Electricity :........ \\
\hline Electricity :............................. \\
\hline Electricity :..................... \\
\hline Sentence $-1: \ldots \ldots \ldots \ldots \ldots \ldots \ldots \ldots$ \\
\hline Sentence -2: ...................... \\
\hline Sentence $-3: \ldots \ldots \ldots \ldots \ldots \ldots \ldots$ \\
\hline
\end{tabular}

Data Analysis

The data were analyzed according to the content analysis method. Firstly, the words associated with the stimulus word were presented in a frequency table that displays the number of times the word were repeated. In this stage, words regarded as unrelated were not taken into consideration. Secondly, the concepts associated with stimulus word were organized in a logical manner and identified themes/categories (Y1ldırım \& Şimşek, 2011). In this process, the sentences associated with the stimulus word helped to identify themes. In addition, the sentences were analyzed taking into account the categories developed by ÖzataYücel \& Özkan (2015), as scientific knowledge, affective knowledge, superficial knowledge and/or examples from daily-life and non-scientific knowledge.

The criteria of categories are shown below:

- Scientific knowledge; scientifically accurate knowledge and associations. 
- Affective knowledge; participants' feelings and thoughts/opinions based on their experience and traditions.

- Superficial knowledge (smattering) and/or examples from daily-life; a slight superficial knowledge is not contain scientific terms and detailed information; and also expressions/examples related to daily life, daily language usage that not overlap with the scientific view.

- Non-scientific knowledge (misconceptions etc.); scientifically inaccurate knowledge or scientific beliefs and expressions that have no basis in existing scientific facts.

To increase the validity of the study, the data analysis process was described and selected representative excerpts from the data for each determined category (Y1ldirım \& Şimşek, 2011). Also, the qualitative data was coded by two researchers and analyzed for consistency. An inter-coder reliability measure recommended by Miles and Huberman (1994), reliability $=$ number of agreements/(total number of agreements + disagreements), was used to calculate the level of agreement between the two researchers. The inter-coder reliability was $83 \%$.

\section{Findings}

The words and frequency values of pre-service primary teachers' associations with the stimulus word electricity are shown in Table 2.

Table 2 The pre-service primary teachers' words associated with the stimulus word "Electricity"

\begin{tabular}{cccccc}
\hline Words & f & Words & f & Words & f \\
\hline Ammeter & 8 & Electrical outlet/receptacle & 4 & Power plants & 4 \\
Ampere & 3 & Electron & 1 & Resistor & 14 \\
Battery holder & 5 & Electrical household appliances & 5 & Salt water & 2 \\
Bill & 3 & Energy & 11 & Series circuits & 8 \\
Brightness & 2 & Generator & 2 & Short circuit & 1 \\
Bulb (lamp) & 26 & Grounding & 1 & Static Electricity & 1 \\
Car & 1 & Gold & 1 & Sugar water & 1 \\
Car Battery & 1 & Heat & 3 & Switch & 14 \\
Cell Battery & 14 & Illumination & 3 & Technology & 5 \\
Charge & 2 & Insulator & 5 & Thomas Edison & 6 \\
Charger & 2 & Invention & 3 & Thunderbolt & 3 \\
Copper cable & 1 & Light & 15 & Transformer & 4 \\
Current & 15 & Lightning & 3 & Traffic lights & 1 \\
Communication & 1 & Light bulb holder & 8 & Volt & 9 \\
Conductor & 6 & Need & 6 & Voltage & 1 \\
Dam & 2 & Nikola Tesla & 1 & Voltmeter & 3 \\
Conductivity & 5 & Parallel circuits & 7 & Water & 4 \\
Conducting wire & 3 & Positive and negative ions & 2 & Watts & 3 \\
Electric circuit & 11 & Positive and negative poles & 4 & Windmill & 2 \\
\hline
\end{tabular}




\begin{tabular}{cccc}
\hline Electric cable & 9 & Power & 3 \\
Electric shock & 9 & Power supply & 5 \\
\hline
\end{tabular}

As seen in table 2, the total number of words associated with the concept of electricity is 61. The most repeated words associated with the stimulus word by PSPTs are the bulb, light, current, switch, resistor, cell battery, electric circuit, and energy.

The categories that represent the cognitive structure of PSPTs regarding electricity are shown in Table 3.

Table 3 Classification of pre-service primary teachers' associations with the stimulus word electricity

\begin{tabular}{|c|c|c|c|c|c|}
\hline Category & Concept \& Frequency & Total & Category & Concept \& Frequency & Total \\
\hline $\begin{array}{l}\text { 1. Circuit } \\
\text { components }\end{array}$ & $\begin{array}{c}\text { Ammeter (8) } \\
\text { Bulb (26) } \\
\text { Switch (14) } \\
\text { Resistor (14) } \\
\text { Light bulb holder (8) } \\
\text { Electric circuit (11) } \\
\text { Electric cable (9) } \\
\text { Power supply (5) } \\
\text { Conducting wire (3) } \\
\text { Cell Battery (14) } \\
\text { Voltmeter (3) } \\
\text { Battery holder (5) }\end{array}$ & 120 & $\begin{array}{l}\text { 6. Relationships } \\
\text { with daily life }\end{array}$ & $\begin{array}{c}\text { Car Battery (1) } \\
\text { Car (1) } \\
\text { Illumination (3) } \\
\text { Electrical household } \\
\text { appliances (5) } \\
\text { Electric shock (9) } \\
\text { Bill (3) } \\
\text { Invention (3) } \\
\text { Communication (1) } \\
\text { Electrical } \\
\text { outlet/receptacle (4) } \\
\text { Charger (2) } \\
\text { Charge (mobile etc.) (2) } \\
\text { Need (6) } \\
\text { Technology (5) } \\
\text { Traffic lights (1) }\end{array}$ & 46 \\
\hline $\begin{array}{l}\text { 2. Circuit } \\
\text { type/structure } \\
\text { and influence }\end{array}$ & $\begin{array}{c}\text { Short circuit (1) } \\
\text { Series circuits (8) } \\
\text { Parallel circuits (7) } \\
\text { Brightness (2) }\end{array}$ & 18 & $\begin{array}{l}\text { 7. Electricity } \\
\text { generation, } \\
\text { distribution and } \\
\text { transformation }\end{array}$ & $\begin{array}{c}\text { Dam (2) } \\
\text { Generator (2) } \\
\text { Windmill (2) } \\
\text { Power plants (4) } \\
\text { Water (4) } \\
\text { Transformer (4) } \\
\text { Power (3) } \\
\text { Voltage (1) } \\
\text { Energy (11) } \\
\text { Heat (3) } \\
\text { Light (15) } \\
\end{array}$ & 51 \\
\hline 3. Conductivity & $\begin{array}{c}\text { Gold (1) } \\
\text { Copper cable (1) } \\
\text { Sugar water (1) } \\
\text { Salt water (2) } \\
\text { Conductor (6) } \\
\text { Conductivity (5) } \\
\text { Insulator (5) } \\
\text { Grounding (1) }\end{array}$ & 22 & $\begin{array}{l}\text { 8. Electric charge } \\
\text { \& current }\end{array}$ & $\begin{array}{c}\text { Current (15) } \\
\text { Positive and negative } \\
\text { ions (2) } \\
\text { Positive and negative } \\
\text { poles (4) } \\
\text { Electron (1) } \\
\text { Static Electricity (1) }\end{array}$ & 23 \\
\hline 4. Scientists & $\begin{array}{c}\text { Thomas Edison (6) } \\
\text { Nicola Tesla (1) }\end{array}$ & 7 & 9. Units & $\begin{array}{c}\text { Ampere (3) } \\
\text { Watts (3) } \\
\text { Volt (9) }\end{array}$ & 15 \\
\hline $\begin{array}{l}\text { 5. Natural } \\
\text { phenomena }\end{array}$ & $\begin{array}{l}\text { Lightning (3) } \\
\text { Thunderbolt (3) }\end{array}$ & 6 & & & \\
\hline
\end{tabular}


As seen in table 3, the words associated with electricity are gathered under 9 categories revealing the cognitive structure of participants. The most prominent category is circuit components. A map of cognitive structure reflecting the pre-service primary teachers' organization of electricity concept is given in Figure 1.

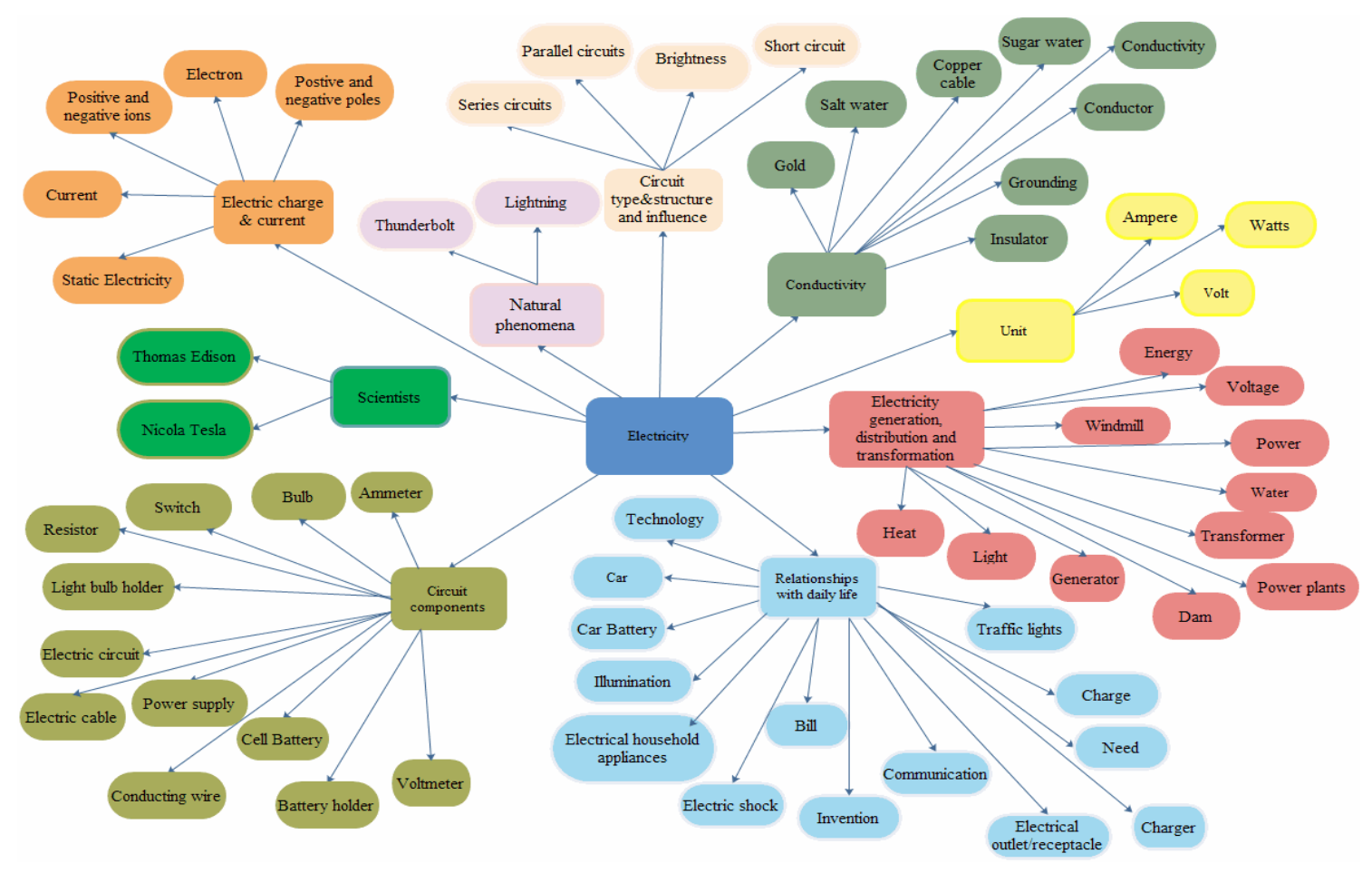

Figure 1 The map of pre-service primary teachers' cognitive structures related to electricity

The classification of sentences which are formed regarding electricity by the participants and some examples of the sentences are shown in Table 4.

Table 4 Classification of sentences formed by participants in relation to the concept of "electricity"

\begin{tabular}{|c|c|c|}
\hline Categories & Examples of sentences & f \\
\hline $\begin{array}{l}\text { Scientific } \\
\text { knowledge }\end{array}$ & $\begin{array}{r}\text {-Electric circuit consists of cell battery, light bulb holder, socket, conducting } \\
\text { wires and switch. } \\
\text {-Electrical energy is a type of energy such as heat, light. } \\
\text {-There is a fundamental need for technology which can be produced with the help } \\
\text { of hydroelectric power plants, wind mills and dams. } \\
\text { - Electric current is measured by ammeter in an electric circuit. } \\
\text {-If identical light bulbs are connected in parallel, the brightness of each light bulb } \\
\text { is the same. } \\
\text {-Serial and parallel connections have different effects on the brightness of light } \\
\text { bulbs. }\end{array}$ & 24 \\
\hline
\end{tabular}

Necatibey Eğitim Fakültesi Elektronik Fen ve Matematik Eğitimi Dergisi

Necatibey Faculty of Education, Electronic Journal of Science and Mathematics Education 


\begin{tabular}{|c|c|c|}
\hline $\begin{array}{l}\text { Affective } \\
\text { knowledge }\end{array}$ & $\begin{array}{r}\text {-Electricity is the greatest invention for humanity. } \\
\text {-It is today's need which facilitates our lives. } \\
\text { - It facilitates our lives, provides ease in household chores and transportation. } \\
- \text { It ruins social life. } \\
\text {-Social life ended with electricity. } \\
\text {-It enhances social life. } \\
\text { - It sometimes influences peoples' lives positively, sometimes negatively. For } \\
\text { example, during a cardiac arrest an electric shock is given and the individual is } \\
\text { resuscitated. } \\
\text {-It is used as an illegal source of energy [electricity theft] } \\
\text {-Electricity is indispensable in today's world. }\end{array}$ & 13 \\
\hline $\begin{array}{c}\text { Superficial } \\
\text { knowledge } \\
\text { (smattering) } \\
\text { and/or examples } \\
\text { from daily life }\end{array}$ & $\begin{array}{c}\text {-It strikes like lightning. } \\
\text { - It is a type of energy serving to meet people's needs in many areas, such as } \\
\text { heating and lighting. } \\
\text { - Charging is carried out with electricity } \\
\text { - We benefit from electricity thanks to the bulb. } \\
\text {-Household appliances work with electricity due to a cable connected into an } \\
\text { electrical outlet. } \\
\text {-The cell battery in an electric circuit will affect the brightness of the bulb. }\end{array}$ & 22 \\
\hline $\begin{array}{l}\text { Non-scientific } \\
\text { knowledge } \\
\text { (misconceptions } \\
\text { etc.) }\end{array}$ & $\begin{array}{r}\text { - Electricity is generated from water's energy. } \\
\text { - Unit of electricity is volt. } \\
\text { - Electricity is a power supply consisting of resistor, brightness, current intensity } \\
\text { and cables. } \\
\text {-Electricity is made up of parts such as cell battery, light bulb holder, battery } \\
\text { holder, conducting wire, resistor, and bulb. } \\
\text { - It is a type of energy has positive and negative poles. } \\
\text { - When we open the switch in circuit [an open circuit], electricity passes through } \\
\text { the circuit and provides energy. } \\
\text {-Electricity [electrical energy] is a source of light, comes out from a cell battery } \\
\text { to turn on the bulb in a circuit. } \\
\text {-Electricity is the power which enables us to use various household appliances. } \\
\text {-When open the switch, it illuminates surroundings with the help of a lamp. }\end{array}$ & 22 \\
\hline
\end{tabular}

The findings in Table 4 indicate that in PSPTs' minds, the concept of electricity is generally associated with the simple electric circuits. Also, electricity concept was often used instead of the electric circuit by participants in non-scientific way. Similarly, the following excerpts are representative of several participants' perceptions about the status of the switch in an electric circuit: "When we open the switch in circuit [an open circuit], electricity passes through the circuit and provides energy." and "When open the switch, it [electricity] illuminates surroundings...". In addition, some participants indicated that electricity is stored in the battery in excerpt such as the following: "Electricity ... comes out from a cell battery ... in a circuit."

\section{Discussion and Conclusion}

This study sought to gain an understanding of how are pre-service primary teachers' (PSPTs) cognitive structures regarding electricity. It is determined that the connections among the concepts within the framework of the concept of electricity which is assumed to reveal the 
cognitive structures of the PSPTs are divided into 9 categories. These categories that reveal the PSPTs" cognitive structures are "circuit components", "circuit type/structure and influence", "conductivity", "electric charge \& current", "natural phenomena", "relationships with daily life", "electricity generation, distribution and transformation", "scientists", and "units". It is clearly seen that the categories of "circuit elements", "relationship with daily life" and "electricity generation, distribution and transformation" have come to the fore. The findings showed that the most used words related to electricity were bulb, light, current, resistor, switch, and cell battery. In this respect, it is not surprising that the most obvious category was circuit components. Usually teaching the fundamental concepts of electricity in association with electric circuits at many educational levels may be the main reasons for this situation. Similarly, participants' expressions such as "Electricity is made up of parts such as cell battery, light bulb holder, battery holder, conducting wire, resistor, and bulb." in nonscientific knowledge category may be a consequence of past learning experiences that are often focus on electric circuits to teach electricity and related concepts. Moreover, the words produced related to electricity by PSPTs were not high-level concepts of electricity and they were generally based on limited knowledge taught at primary and middle school levels. This may be a result of the fact that PSPTs took a limited number of physics courses at high school and university levels.

It is seen that the distributions of PSPTs' expressions in the categories are similar rates except the affective knowledge category which is lower rate than the others (see Table 4). The findings indicated that PSPTs have as much non-scientific knowledge and superficial knowledge as they have scientific knowledge about electricity.

The findings showed also that for some participants, electricity, (1) the greatest invention for mankind, (2) one of the most important technological needs, (3) facilitates the life, and (4) ruins and enhances social life. The findings indicated that electricity was seen as a requirement for the use of technology. For this reason, in particular, participants' comments about the effects of electricity on social life can be considered as a reflection of their ideas about being social via communication technologies (social networking services, etc.).

The expressions that some participants stated, such as "Electricity [electrical energy] ... comes out from a cell battery... in a circuit" indicate that they have the thought that electrical energy is stored in the battery. In other words, these participants thought electrical energy is already in the battery. Quinn (2014) emphasized that a kind of energy is certainly stored in a battery and the energy that can be released through a chemical process that occurs when 
terminals are connected to a circuit. As it is known, electrical energy is not already in the battery. Similarly, in the studies carried out by Cheng \& Kwen (1998), Duit \& Rhöneck (1997) and Çıldır \& Şen (2006), it was stated that students have the idea that electricity/electrical energy is stored in the battery.

Some participants uttered expressions such as "When open the switch [an open circuit], it [electricity] illuminates surroundings..." and "When we open the switch in circuit, electricity passes through the circuit and provides energy". A switch is a device that allows controlling the flow of current in an electric circuit. As it is known, in an electric circuit, a switch which is closed causes light the lamp. When the switch is open, creating a gap in the electric circuit, and the lamp goes off. Briefly, according to the "open" and "closed" terminology of circuits, a switch that makes a gap between terminals in the electric circuit is called a closed switch. Conversely, a switch that is breaking continuity is called an open switch. In daily life of Turkish, phrases such as "open the switch" refer to flicking a switch the on position to turn light on and "close the switch" to refer to flicking a switch the off position to turn light off are used. Especially, this terminology is often confusing to the students, when using phrases such as a closed switch, an open switch, closed circuit and open circuit in teaching electrical circuit in Turkey context. Küçüközer (2004) and Küçüközer \& Kocakülah (2007) indicated that Turkish students have the specific misconception that is the lamp goes off when switch is closed due to daily life language. Uzun, Alev \& Karal (2013) pointed out that using of concepts in everyday language when explaining a scientific phenomenon may lead students to hold misunderstandings or misconceptions. Considering that the participants in this study were pre-service primary teachers, raise awareness about not overlapping with a scientific perspective, including everyday life experiences, and highlighting expressions which may cause misunderstandings or/and misconceptions, can be achieved within the scope of teacher training especially during subject area courses. Thus, pre-service teachers as future teachers can avoid using these types of expressions in their teaching environments. Lee \& Law (2001) noted that it is important for teachers to use a clearer and more appropriate language so as to allow students to see the difference between scientific concepts and daily life-concepts and to encourage students in this regard.

In summary, the word association test, frequently referenced in literature, was used in this study with the aim of determining the cognitive structures of participants regarding electricity presented as a stimulus word. The sentences formed by participants helped to define the categories and to identify scientific accuracy of the connections during the analysis 
process. In this study, similar to other studies in the literature, participants were asked to generate three sentences related to stimulus word, but it is considered that a greater number of sentences are needed to show the cognitive structure more clearly. Therefore, it is thought that forming a sentence for each of the words associated with stimulus word may contribute more to determine the categories which are assumed to reflected the cognitive structures. Furthermore, interviews may also make an important contribution to this process. Especially, the word association tests taking into consideration the above-mentioned recommendations may provide benefits the identification of cognitive structures and accordingly in determining the interventions required in the teaching process.

\section{References}

Akdeniz, A. R., Pektaş, U., \& Yiğit, N. (2000). İlköğretim 8. sınıf öğrencilerinin temel fizik kavramlarını anlama düzeyi. Hacettepe Üniversitesi Eğitim Fakültesi Dergisi, 19, 5-14.

Aykutlu, I. \& Şen, A. İ. (2012). Üç aşamalı test, kavram haritası ve anoloji kullanılarak lise öğrencilerinin elektrik akımı konusundaki kavram yanılgılarının belirlenmesi. Eğitim ve Bilim, 37(166), 275-288.

Bahar, M., Johnstone, A.H., \& Sutcliffe, R.G. (1999). Investigation of students' cognitive structure in elementary genetics through word association tests. Journal of Biological Education, 33(3), 134-141.

Bahar, M. \& Ozatli, N. S. (2003). Kelime iletisim test yontemi ile lise 1. sinif ogrencilerinin canlilarin temel bilesenleri konusundaki bilissel yapilarinin arastirilmasi. Ballkesir Üniversitesi Fen Bilimleri Enstitüsü Dergisi, 5(2), 75-85.

Canbazoğlu-Bilici, S. (2016). An examination of science teachers' knowledge structures towards technology. International Journal of Environmental \& Science Education, 11(5), 571-586.

Cheng, A. K. \& Kwen, B. H. (1998). Primary pupils' conceptions about some aspects of electricity, Australian Association for Research in Education Conference, Adelaide, Australia. Retrieved on 15-Sep.-2016, URL:

https://repository.nie.edu.sg/bitstream/10497/4610/1/ang98205_a.pdf

Çıldır, I. (2005). Lise ögrencilerinin elektrik akımı konusundaki kavram yanılgılarının kavram haritalarıyla belirlenmesi. Yüksek Lisans Tezi, Hacettepe Üniversitesi, Ankara. 
Çıldır, I. \& Şen, A. İ. (2006). Lise öğrencilerinin elektrik akımı konusundaki kavram yanılgılarının kavram haritalarıyla belirlenmesi [Identification of high school students' misconception about electric current by concept maps]. Hacettepe Üniversitesi Ĕ̈itim Fakültesi Dergisi (H. U. Journal of Education), 30, 92-101.

Demirci, N. \& Çirkinoğlu, A. (2004). Determining students' preconceptions/misconceptions in electricity and magnetism. Journal of Turkish Science Education, 1(2), 116-138.

Dilber, R. \& Düzgün, B. (2008). Effectiveness of analogy on students' success and elimination of misconceptions. Latin American Journal of Physics Education, 2(3), 174183.

Duit, R. \& Rhöneck, C. V. (1997). Learning and understanding key concepts of electricity. Retrieved on 15-Sep.-2016, URL: http://kdfls1.troja.mff.cuni.cz/publications/teach1/ConnectingResInPhysEducWithTeacherEduc_Vol_1.pdf

Ercan, F., Taşdere, A, \& Ercan, N. (2010). Kelime ilişkilendirme testi aracılı̆̆ıyla bilişsel yapının ve kavramsal değişimin gözlenmesi [Observation of cognitive structure and conceptual changes through word associations tests]. Türk Fen Eğitimi Dergisi, 7(2), 136-154.

Garner, B. K. (2007). Getting to got it!: Helping struggling students learn how to learn. Alexandria, VA: Association for Supervision and Curriculum Development.

Gökulu, A. \& Koç, G. (2016). Sınıf öğretmenlerinin fen öğretimi dersine yönelik öz yeterlilik inançları ve görüşleri [Elementary teacher's self-efficacy beliefs regarding science teaching lesson and opinions]. The Journal of Academic Social Science Studies, 43, 383-396.

Gussarsky, E. \& Gorodetsky, M. (1990). On the concept "Chemical Equilibrium": The associative framework. Journal of Research in Science Teaching, 27(3), 197-204.

Hovardas, T. \& Korfiatis, K. J. (2006). Word associations as a tool for assessing conceptual change in science education. Learning and Instruction, 16(5), 416-432.

Ifenthaler, D., Masduki, I., \& Seel, N. M. (2011). The mystery of cognitive structure and how we can detect it: tracking the development of cognitive structures over time. Instructional Science, 39(1), 41-61.

Işıklı, M., Taşdere, A., \& Göz, N. L. (2011). Kelime ilişkilendirme testi aracılığıyla öğretmen adaylarının Atatürk ilkelerine yönelik bilişsel yapılarının incelenmesi [Investigation 
teacher candidates'cognitive structure about principles of Ataturk through word association test]. Uşak Üniversitesi Sosyal Bilimleri Dergisi, 4(1), 50-72.

Karal, S. I., Alev, N., \& Yiğit, N. (2009). Öğretmen Adaylarının Elektrikte Alan Bilgisi, $e$ Journal of New World Sciences Academy, 4(4), 1450-1467.

Kurt, H. (2013). Biyoloji öğretmen adaylarının "Enzim” konusundaki bilişsel yapılarının belirlenmesi [Determining biology student teachers' cognitive structure on the concept of "Enzyme"]. GEFAD/GUJGEF, 33(2), 211-243.

Kurt, H. \& Ekici, G. (2013). What is a Virus? Prospective biology teachers' cognitive structure on the concept of virus. International Online Journal of Educational Sciences, 5(3), 736-756.

Kostova, Z. \& Radoynovska, B. (2008). Word association test for studying conceptual structures of teachers and students. Bulgarian Journal of Science and Education Policy (BJSEP), 2(2), 209-231.

Küçüközer, H. (2004). Yapılandırmacı öğrenme kuramına dayalı olarak geliştirilen öğretim modelinin lise 1. sinıf ögrencilerinin basit elektrik devrelerine ilişkin kavramsal anlamalarına etkisi. Yayımlanmamış Doktora tezi, Balıkesir Üniversitesi, Balıkesir.

Küçüközer, H. \& Kocakülah, S. (2007). Secondary School Students’ Misconceptions about Simple Electric Circuits. Journal of Turkish Science Education, 4(1), 101-115.

Lee, Y. \& Law, N. (2001). Explorations in promoting conceptual change in electrical concepts via ontological category shift. International Journal Science Education, 23(2), 111-149.

Miles, M. B. \& Huberman, A. M. (1994). Qualitative data analysis (2nd edition). Thousand Oaks, CA: Sage Publications.

Mulhall, P., McKittrick, B., \& Gunstone, R. (2001). A Perspective on the resolution of confusions in the teaching of electricity. Research in Science Education, 31(4), 575587.

Nartgün, Z. (2006). Fen ve teknoloji öğretiminde ölçme ve değerlendirme. M. Bahar (Ed.), Fen ve teknoloji öğretimi. Ankara: Pegema Yayıncılık.

Öner Armağan, F. (2015). Cognitive structures of elementary school students: What is Science? European Journal of Physics Education, 6(2), 54-73. 
Özata-Yücel, E. \& Özkan, M. (2015). Determination of secondary school students' cognitive structure, and misconception in ecological concepts through word association test. Educational Research and Reviews, 10(5), 660-674.

Quinn, H. R. (2014). A Physicist's Musing on Teaching about Energy. In R.F. Chen et al. (Eds.), Teaching and Learning of Energy in K-12 Education (pp. 15-36). Switzerland: Springer International Publishing.

Shavelson, R. J. (1972). Some aspects of the correspondence between content structure and cognitive structure in physics instruction. Journal of Educational Psychology, 63(3), 225-234.

Shavelson, R. J., (1974). Methods for examining representations of a subject-matter structure in a student's memory. Journal of Research in Science Teaching, 11(3), 231- 249.

Shipstone, D. M. (1988). Students' understanding of simple electrical circuits. Physics Education. 23(2), 92-96.

Shipstone, D. M, Von Rhöneck, C., Jung, W., Kärrqvist, C., Dupin, J. J., Joshua, S., \& Licht, P. (1988). A study of students' understanding of electricity in five European countries. International Journal of Science Education, 10(3), 303-316.

Şaşmaz-Ören, F. (2014). Fen bilimlerinde alternatif ölçme-değerlendirme. Ş. S. Anagün \& N. Duban (Eds.), Fen Bilimleri Öğretimi. Ankara: Anı Yayıncılık.

Uzun, S., Alev, N., \& Karal, I. S. (2013). A cross-age study of an understanding of light and sight concepts in physics. Science Education International, 24(2), 129-149.

Taşdere, A., Özsevgeç, T., \& Türkmen, L. (2014). Bilimin doğasına yönelik tamamlayıcı bir ölçme aracı: Kelime ilişkilendirme testi. Fen Ĕ̆itimi ve Araştırmaları Derneği-Fen Bilimleri Öğretimi Dergisi, 2(2), 129-144.

Tsai, C. C. \& Huang, C. M. (2002). Exploring students' cognitive structures in learning science: a review of relevant methods. Journal of Biological Education, 36(4), 163-169.

Yıldırım, A. \& Şimşek, H. (2011). Sosyal bilimlerde nitel araştırma yöntemleri. Ankara: Seçkin Yayıncılık.

Yıldırım, H.İ, Yalçın, N., Şensoy, Ö., \& Akçay, S. (2008). İlköğretim 6., 7. ve 8. sınıf öğrencilerinin elektrik akımı konusunda sahip oldukları kavram yanılgıları. Kastamonu Ĕ̈itim Dergisi, 16(1), 67-82. 